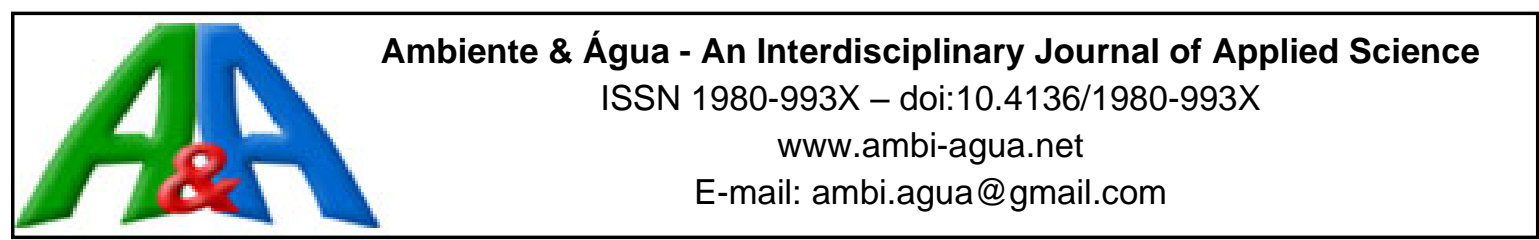

\title{
New records of the sponge Radiospongilla inesi (Porifera: Spongilidae) and the slug Omalonyx matheroni (Gastropoda: Succineidae) in the Vale do Paraíba, southeast Brazil
}

doi:10.4136/ambi-agua.2321

Received: 18 Nov. 2019; Accepted: 20 Dec. 2019

\author{
Cláudia Regina da Silva Leite'; ; Valter José Cobo* \\ ${ }^{1}$ Programa de Pós-Graduação em Ciências Ambientais. Universidade de Taubaté (UNITAU), Rua Visconde do \\ Rio Branco, n 210, CEP: 12020-240, Taubaté, SP, Brazil. E-mail: clau.silvaleite@ terra.com.br \\ ${ }^{2}$ Instituto Básico de Biociências. Universidade de Taubaté (UNITAU), Av. Tiradentes, n 500, CEP: 12030-180, \\ Taubaté, SP, Brazil \\ "Corresponding author. E-mail: vjcobo@gmail.com
}

\begin{abstract}
This report provides the new record of the sponge Radiospongilla inesi and the slug Omalonyx matheroni for the Vale do Paraiba, State of São Paulo, southeastern Brazil, besides the symbiosis among $R$. inesi and individuals of some benthic macroinvertebrates. Monthly collections were carried out in the Ribeirão dos Mottas, with a $0.5 \mathrm{~cm}$ sieve in the edge vegetation, as well as collections by hand. Three specimens of $R$. inesi were found, from a lotic environment under pebbles. In addition, individuals of four insect families, Sisyridae, Hydropsychidae, Chironomidae e Simuliidae, were found on the sponge aquiferous system. Six individuals of the semi-aquatic slug $O$. matheroni were also caught under rocks and cans. Despite the sponges are commonly found in the most of the environments, the freshwater species represents one of the most unknown animal groups of the world. $R$. inesi was report at first time in Brazil in Pernambuco State, northeastern Brazil region, and this report represents just the second record of this species in Brazil, and the first time to the southeastern region. The presence of individuals of four insect families pointing out the importance of $R$. inesi on the life history of these animals. Despite some records of Omalonix sp. to the São Paulo State, this report seems to be the first record of the $O$. matheroni to the Vale do Paraíba, northern of the São Paulo State.
\end{abstract}

Keywords: geographic distribution enlargement, macroinvertebrates, São Paulo State, species conservation.

\section{Novos registros da esponja Radiospongilla inesi (Porifera: Spongilidae) e da lesma Omalonyx matheroni (Gastropoda: Succineidae) no Vale do Paraíba, sudeste do Brasil}

\section{RESUMO}

O presente trabalho apresenta o novo registro da esponja Radiospongilla inesi e da lesma Omalonyx matheroni para o Vale do Paraiba, Estado de São Paulo, sudeste do Brasil, além da simbiose entre $R$. inesi e indivíduos de alguns macroinvertebrados bentônicos. Coletas foram conduzidas mensalmente no Ribeirão dos Mottas, com uma peneira de malha de 0.5 , na 
vegetação marginal, além de coletas manuais. Três exemplares de $R$. inesi foram obtidos em ambiente lótico, sob rochas. Além disso, exemplares de quatro famílias de insetos, Sisyridae, Hydropsychidae, Chironomidae e Simuliidae, foram encontrados no sistema aquífero das esponjas. Seis indivíduos da lesma semi-aquática $O$. matheroni também foram encontrados sob rochas e latas de alumínio descartadas no ambiente. Apesar dos Porifera serem comumente encontrados na maioria dos ambientes marinhos, eles representam um dos grupos menos conhecidos em ambientes de água doce. $R$. inesi foi reportada para o Brasil pela primeira vez, no Estado de Pernambuco, na região nordeste, de modo que este representa o segundo registro para o Brasil e o primeiro registro para a região sudeste. Além disso, a presença de macroinvertebrados associados com a esponja indica a importância de $R$. inesi no ciclo de vidas desses animais. Apesar de haver alguns registros de Omalonix sp. Para o Estado de São Paulo, este registro parece ser o primeiro para $O$. matheroni para a porção paulista do Vale do Paraíba.

Palavras-chave: ampliação da distribuição geográfica, conservação de espécies, Estado de São Paulo, macroinvertebrados.

\section{INTRODUCTION}

Freshwater sponges of the monophyletic order Spongillida, is the unique lineage of demosponges that colonized lentic and lotic systems sometime in the PermoCarboniferous (Schuster et al. 2018; Kenny et al. 2019).

The genus Radiospongilla Penney \& Racek, 1968, present gemmoscleres radially arranged on gemmules and microscleres absents. This species is widely distributed over the world and recorded in all zoogeographical regions, except for Antarctica (Manconi \& Pronzato, 2007; Osborn et al. 2008). Along the 18 species described for the genus Radiospongilla, only three are recorded in the Neotropical Region, $R$. crateriformis (Potts, 1882), distributed in Mexico, United States, Suriname, Canada, Barbados, Cuba, Costa Rica, China and Japan (see Nicácio et al., 2011). R. amazonensis Volkmer-Ribeiro \& Maciel, 1983, restricted to Brazil, distributed in seven of the twelve Brazilian hydrographic basins (Pinheiro, 2007) and $R$. inesi Nicácio \& Pinheiro, 2011, currently recorded exclusively in Brazil, Eastern North Atlantic Basin, in the Pernambuco state.

Moreover, sponges are commonly related to symbiotic interactions, which include crustaceans (Ribeiro et al., 2003, Abdo, 2007), polychaets (Çinar et al., 2002), besides echinoderms and fishes (Henkel \& Pawlik, 2005).

The genus Omalonyx d'Orbigny, 1837 comprises hermaphrodite slugs that have two blackish longitudinal lines and dispersal spots over the body (Arruda et al., 2006, Arruda et al., 2009). They are distributed over the Neotropical area, in the West Indies and South America. According Coscarelli et al. (2018), currently, there are six Omalonix species recognized over the world, which are Omalonix unguis (d'Orbigny, 1837), Omalonix matheronii (Potiez \& Michaud, 1835), Omalonix convexus (Heynemann, 1868), Omalonix brasiliensis (Simroth, 1869), Omalonix geayi Tillier, 1980 and Omalonix pattersonae (Tillier, 1981).

This report provides the new record of the sponge Radiospongilla inesi and the slug Omalonyx matheroni for the Vale do Paraiba, southeastern Brazil region, in the municipality of Guaratinguetá, State of São Paulo, besides the symbiosis among R. inesi and individuals of some benthic macroinvertebrates.

\section{MATERIAL AND METHODS}

Monthly collections were carried out from September 2014 to August 2015 in the Ribeirão

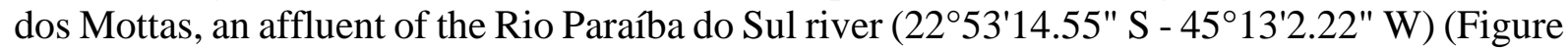
1), as a part of the broad aquatic macroinvertebrate research. The basin of the Ribeirão dos

Rev. Ambient. Água vol. 7 (supplement) - Taubaté 2019 
Mottas comprise a stream that ends on the right edge of the Paraíba do Sul river, included on the elevation system of the Serra do Mar, in northeastern of the São Paulo State. A single person performed the collections with a $0.5 \mathrm{~cm}$ sieve during 30 minutes per month, in the edge vegetation, as well as collections by hand. All organisms obtained during these collections were stored in labeled jars, filled with alcohol $70 \%$ and transferred to the Laboratory of Zoology of the Universidade de Taubaté to the analysis.

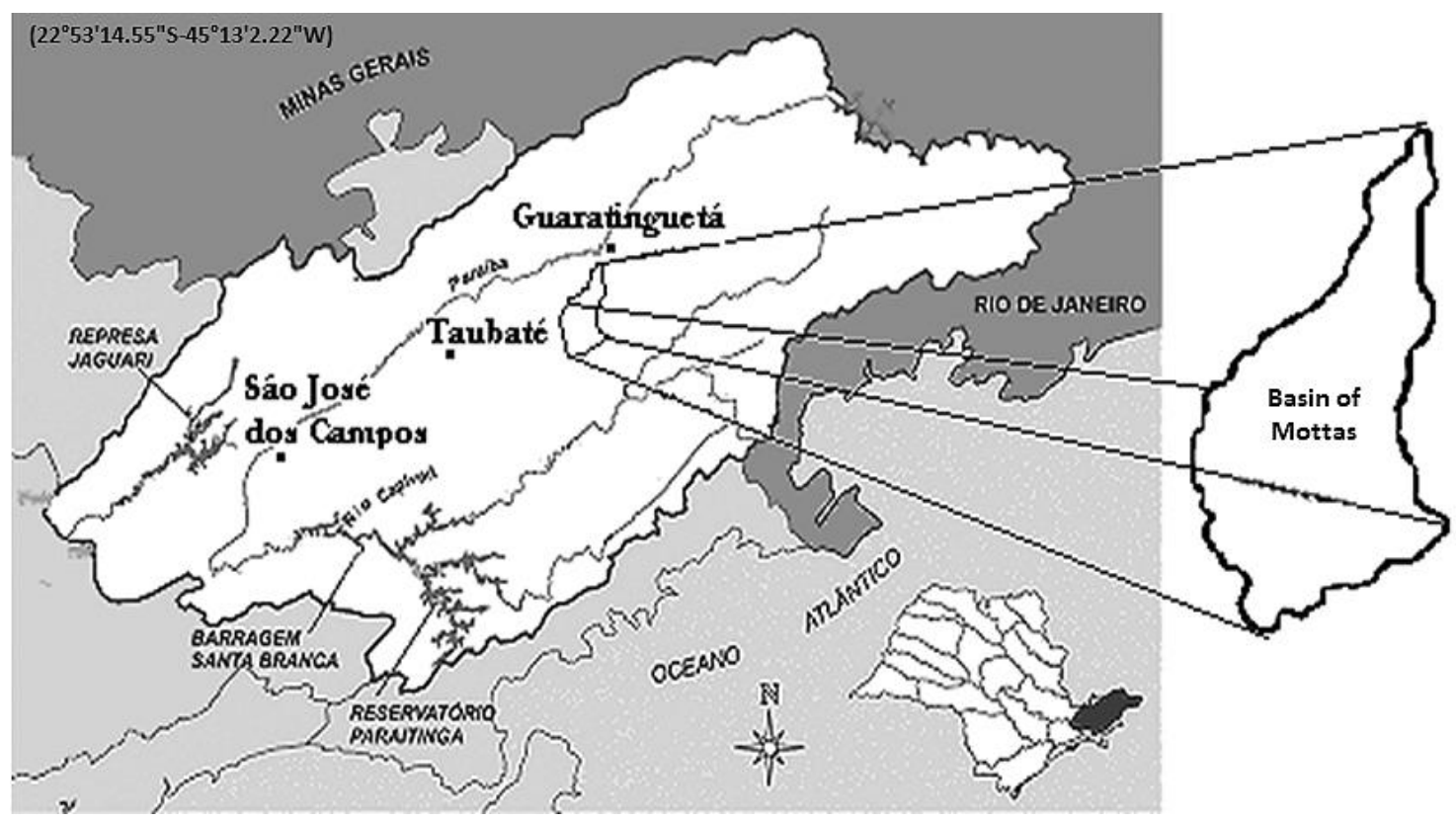

Figure 1. Map of the Basin of Mottas, the location of the collections.

\section{RESULTS AND DISCUSSION}

Among the sampled material three specimens of Radiospongilla inesi (Figure 2) were found, from a lotic environment under pebbles, in the Ribeirão dos Mottas, between September and November 2014. The taxonomic identification of the sponges was confirmed and the material is deposited in the Scientific Museum of the Universidade Federal do Pernambuco UFPE, (\#UFPEPOR 2153). In addition, individuals of four insect families, Sisyridae, Hydropsychidae, Chironomidae e Simuliidae, were found on the sponge aquiferous system. Six individuals of the semi-aquatic slug Omalonyx matheroni (Figure 3), were caught at May 2015, under rocks and cans thrown away as garbage, near the dam of the Ribeirão dos Mottas. These slugs remain storage in the Laboratory of Zoology of the Universidade de Taubaté.

Despite the sponges are commonly found in the most of the environments, the freshwater species represents one of the most unknown animal groups of the world. Currently, the sponge fauna comprising more than 8,000 species, which less than 200 are from freshwater environments (Pinheiro, 2007). In Brazil there are circa of $25 \%$ of this total, being the most of them recorded in the Rio Grande do Sul State and Amazonic region (Nicacio et al., 2011).

Radiospongilla inesi is a yellowish color sponge that ranging from volcano-shaped, encrusting or massive, presenting a large conspicuous osculum and/or scattered small oscula. It was report at first time in Brazil in the Ribeirão do Prata, Pernambuco State, northeastern Brazil region (Nicacio et al., 2011), and this report represents just the second record of this species in Brazil, and the first time to the southeastern region. 


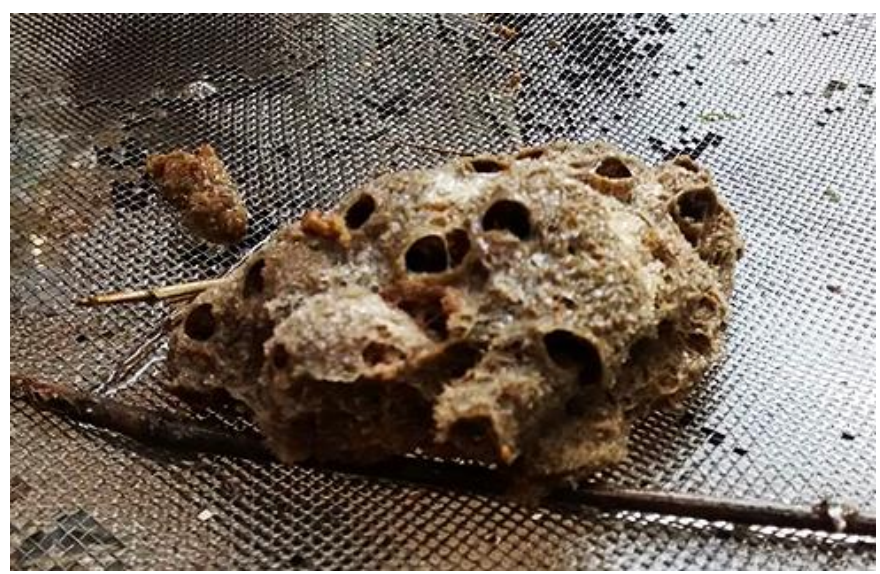

Figure 2. Radiospongilla inesi sampled in the Ribeirão dos Mottas (credits: Leite, C. R. S.).

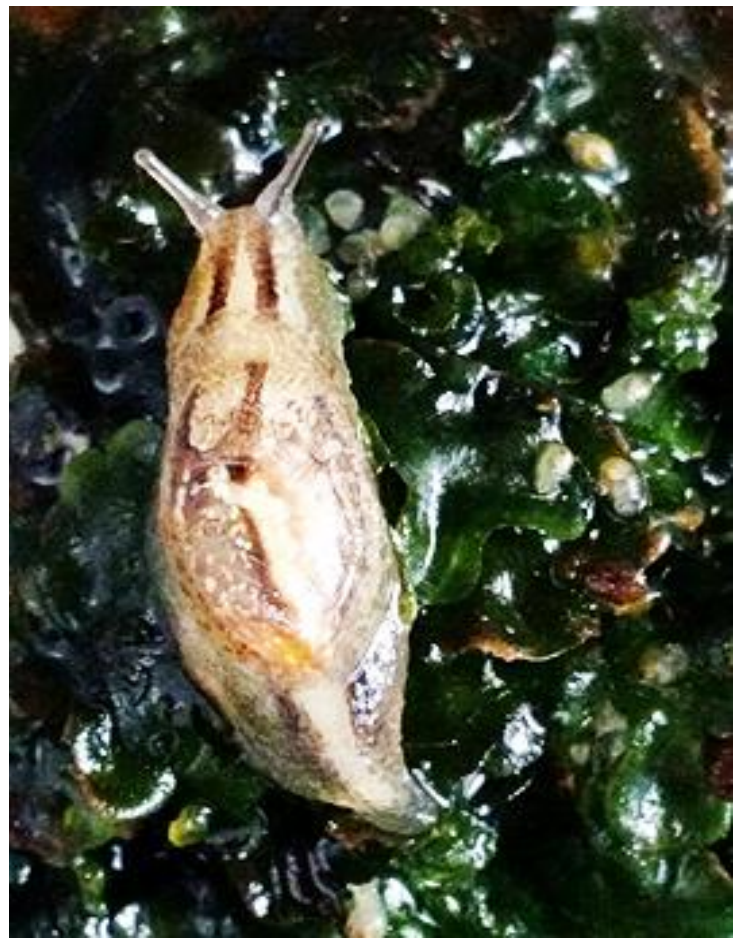

Figure 3. Omalonyx matheroni sampled in the Ribeirão dos Mottas (credits: Leite, C. R. S.).

Symbiosis interactions including sponges is widely reported, in fact they capability to establish a great diversity of relationships (mutualism, commensalism and parasitism with unicellular and multicellular organisms) (see Ávila et al., 2007) is one of their more interesting characteristics. The presence of individuals of four insect families pointing out the importance of $R$. inesi on the life history of these animals, as oviposition substratum (Huggibs, 1980), shelter and as source of food (Stoaks et al., 1983).

Species of the genus Omalonyx have broad distribution on the Central and South Americas, found in swamps and lake banks, or under the emergent vegetation of the freshwater systems (Poi De Neiff \& Casco, 2003). The slugs Omalonyx matheroni present records especially in the Amazonian region, with some feel reports to Central West, Southeaster and South regions (Coscarelli et al., 2018). Despite some records of Omalonix sp. to the São Paulo State, this 
report seems to be the first record of the O. matheroni to the Vale do Paraíba, northern of the São Paulo State.

\section{CONCLUSIONS}

Despite the biological information concerning these two species remain scarce, this report provides new records of occurrence of freshwater fauna, which represents promising candidates to bioindicators for the environmental quality. Moreover, additional researches will provide meaningful help to understand the biology of the benthic organisms of the Paraiba do Sul basin, in order to subside the development of conservation policies and environmental laws.

\section{REFERENCES}

ABDO, D. A. Endofauna differences between two temperate marine sponges (Demospongiae; Haplosclerida; Chalinidae) from southwest Australia. Marine Biology, v.152: 845-854, 2007.

ARRUDA, J. O.; GOMES, S. R.; RAMIREZ, R.; THOMÉ, J. W. Morfoanatomia de duas espécies do gênero Omalonyx (Mollusca, Gastropoda, Succineidae) com novo registro para Minas Gerais, Brasil. Biociências, v. 14, n 1: 61-70, 2006.

ARRUDA, J. O.; PEREIRA, D.; BERGONCI, P. E. A.; SANTOS, C. P.; MANSUR, M. C. D. Novos registros de Omalonyx matheroni (Potiez \& Michaud, 1835) (Mollusca: Gastropoda: Succineidae) para os Estados de São Paulo e Paraná, Brasil. Biotemas. v. 22:187-190, 2009.

ÁVILA, E.; CARBALlO, J. L.; CRUZ-BARRAZA, J. A. Symbiotic relationships between sponges and other organism from the Sea of Cortes (Mexican Pacific coast): same problems, same solutions. In: Porifera Research: Biodiversity, Innovation and Sustainability: Museu Nacional, Rio de Janeiro: 147-156, 2007.

ÇINAR, M. E.; KATAGAN, T.; ERGEN, Z.; SEZGIN, M. Zoobenthos inhabiting Sarcotragus muscarum (Porifera: Demospongiae) from the Aegean Sea. Hydrobiologia, v. 482: 107117, 2002.

COSCARELli, D.; MONTRESOR, L. C.; RUSSO, P.; MELO, A. L.; VIDIGAL, T. H. D. A. Predicting the distribution of Omalonyx (Mollusca: Pulmonata: Succineidae) from literature review, museum databases and new sampling efforts in Brazil. Biota Neotropica. 18(1): e20170409. 2018. Disponível em: http://dx.doi.org/10.1590/16760611-BN-2017-0409. Acesso em maio de 2018.

HENKEL, T. P.; PAWLIK, J. R. Habitat use by sponge dwelling brittle stars. Marine Biology, v. 146: 301-13, 2005.

HUGGINS, D. G. The spongillaflies (Neuroptera: Sisyridae) of Kansas. Technical Publications of the State Biological Survey of Kansas, v. 9: 67-70, 1980.

KENNY, N. J.; PLESE, B.; RIESGO, A.; ITSKOVICH, V. B. Symbiosis, Selection, and Novelty: Freshwater Adaptation in the Unique Sponges of Lake Baikal. Molecular Biology Evolution, v. 36, n. 11: 2462-2480, 2019.

MANCONI, R.; PRONZATO, R. Gemmules as a key structure for the adaptive radiation of freshwater sponges: a morphofunctional and biogeographic study. In: Porifera Research: Biodiversity, Innovation and Sustainability. Museu Nacional, Rio de Janeiro, 2007. pp. 61-77, 
NICACIO, G.; SEVERI, W.; PINHEIRO, U. New species of Radiospongilla (Porifera: Spongillidae) from Brazilian inland waters. Zootaxa, v. 3132: 56-63, 2011.

OSBORN, A. W.; FORTEATH, G. N. R.; STANISIC, J. A. New Species of Freshwater Sponge (Porifera: Spongillidae) of the Genus Radiospongilla from Lake Pedder in Tasmania. Papers and Proceedings of the Royal Society of Tasmania, v. 142: 39-44, 2008.

PINHEIRO U. S. Contribuições à Taxonomia e Biogeografia das Esponjas de Águas Continentais Brasileiras. 2007, 220pp. Tese de Doutorado, Universidade Federal do Rio de Janeiro, Rio de Janeiro: Museu Nacional.

POI DE NEIFF, A. S.; CASCO, S. L. Biological agents that accelerate winter decay of Eichhornia crassipes Mart. Solms. In: Ecologia e manejo de macrófitas aquáticas. Maringá: Universidade Estadual de Maringá. 2003. pp. 127-144.

RIBEIRO, S. M.; OMENA, E. P; MURICY, G. Macrofauna associated to Mycale microsigmatosa (Porifera, Demospongiae) in Rio de Janeiro State, SE Brazil. Estuarine and Coastal Shelf Science, v. 57: 951-959, 2003.

SCHUSTER A.; VARGAS, S.; KNAPP, I. S.; POMPONI, S. A.; TOONEN, R. J.; ERPENBECK. D.; WÖRHEIDE, G. Divergence times in demosponges (Porifera): first insights from new mitogenomes and the inclusion of fossils in a birth-death clock model. BMC Evolutionary Biology, v. 18, n. 1:1-14, 2018.

STOAKS, R. D.; NEEL, J. K.; POST, R. L. Observations on North Dakota sponges (Haplosclerina: Spongillidae) and sisyrids (Neuroptera: Sisyridae). Great Lakes Entomologist, v. 16: 171-176, 1983. 